\title{
A broad-range survey of Borrelia burgdorferi sensu lato infection in small mammals in Yunnan Province, China
}

\section{Zhihai He}

Yunnan Institute of Endemic Diseases Control and Prevention, Dali, P.R.China

\section{Baogui Jiang}

State Key Laboratory of Pathogen and Biosecurity, Beijing Institute of Microbiology and Epidemiology, Beijing, P.R.China

\section{Zihou Gao}

Yunnan Institute of Endemic Diseases Control and Prevention, Dali, P.R.China

\section{Zongti Shao}

Yunnan Institute of Endemic Diseases Control and Prevention, Dali, P.R.China

\section{Yun Zhang}

Yunnan Institute of Endemic Diseases Control and Prevention, Dali, P.R.China

\section{Zhengxiang Liu}

Yunnan Institute of Endemic Diseases Control and Prevention, Dali, P.R.China

\section{Yuqiong Li}

Yunnan Institute of Endemic Diseases Control and Prevention, Dali, P.R.China

\section{Ennian Pu}

Yunnan Institute of Endemic Diseases Control and Prevention, Dali, P.R.China

\section{Li Tang}

Yunnan Institute of Endemic Diseases Control and Prevention, Dali, P.R.China

\section{Mingguo Yao}

Yunnan Institute of Endemic Diseases Control and Prevention, Dali, P.R.China

\section{$\mathrm{Na}$ Jia}

State Key Laboratory of Pathogen and Biosecurity, Beijing Institute of Microbiology and Epidemiology, Beijing, P.R.China

\section{Michael E. von Fricken}

George Mason University, Dept. of Global and Community Health, Fairfax, VA, USA

Jiafu Jiang ( $\sim 15810174122 @ 139 . c o m$ )

State Key Laboratory of Pathogen and Biosecurity, Beijing Institute of Microbiology and Epidemiology, Beijing, P.R.China

\section{Chunhong Du}

Yunnan Institute of Endemic Diseases Control and Prevention, Dali, P.R.China 
Research

Keywords: Lyme disease, Borrelia burgdorferi sensu lato, Small mammals, China

Posted Date: December 15th, 2020

DOI: https://doi.org/10.21203/rs.3.rs-124610/v1

License: (c) (i) This work is licensed under a Creative Commons Attribution 4.0 International License. Read Full License 


\section{Abstract}

Background: Lyme disease, caused by Borrelia burgdorferi sensu lato (BBSL), is commonly found in wild and domestic mammals worldwide. In China, human cases of $B$. burgdorferi infections have been identified across a wide distribution, but little direct surveillance of potential small mammal reservoirs has been performed in Yunnan Province, a tropical region in southwestern China. Here we report a thorough investigation of BBSL in small mammals collected from 2011 to 2016 from this region.

Methods: Small mammals were captured using snap traps in 23 counties located in Yunnan Province. DNA was extracted from spleen tissue using DNA blood and tissue kits. A nested PCR targeting the 5S23S rRNA intergenic spacer gene of BBSL was used for pathogen detection. Amplicons of 252bp expected sizes were sequenced directly and analyzed using BLAST algorithm. A phylogenetic tree was constructed using MEGA software and statistical analysis were conducted using SPSS version 17.0.

Results: Overall, 3659 mammals belonging to 57 species were captured at 159 sample sites located in 23 counties in Yunnan Province. Borrelia burgdorferi s.l. was found in 146 mammals (3.99\%), from 30 different species, 20 of which represent the first reported detection in that species. Sequence analysis revealed five genotypes of $B$. burgdorferi s.l., including $B$. afzelii, $B$. burgdorferi sensu stricto, $B$. japonica, B. garinii and B. valaisiana.

Conclusions: Significant differences in prevalence rates of BBSL were observed at varying landscape types and altitudes. Small mammals in forested areas had higher prevalence rates than other landscape types, as did small mammals found at altitudes greater than 2500 meters. The five genotypes of BBSL detected, suggests high genetic diversity within this province.

\section{Background}

Lyme borreliosis (LB) is the most commonly reported vector-borne disease across Europe, North America and Asia [1-4]. The causative agents of LB fall within the species complex $B$. burgdorferi sensu lato (BBSL) mainly including B. garinii, $B$. afzelii, $B$. japonica, and B. valaisiana, and are responsible for a wide spectrum of clinical symptoms. While there have been documented reports of human cases of LB in 30 provinces in China through serum epidemiological investigation as well as molecular gene-typing research $[4,5]$. A little bit information on the prevalence of BBSL in human in Yuanan province [4,5]. Also, the report on BBSL in small mammal reservoirs were about indoors small mammals or some limited local small-scale area. Yunnan Province is of particular interest given its wide topographic range, where the elevation is high in the northwest and low in the southeast, and land features include plateaus, low mountains, hills, high mountains, deep valleys and open river valleys. A high level of small mammal biodiversity exists within this region, many of which may serve as potential reservoirs for BBSL. To evaluate the distribution and genetic diversity of BBSL, as well as the role that small mammals play in transmission, we performed a broad-range, systematic field investigation of BBSL in Yunnan Province. 


\section{Methods}

\section{Collection of Small Mammal Samples}

From 2011 to 2016, small mammals were captured using animal snap traps set at agricultural, forested, and residential areas, with elevation ranging from 530 to $4300 \mathrm{~m}$. A total of 159 sample sites located in 23 counties across Yunnan Province (Figure 1) were surveyed. Two hundred snap traps per sample site were placed for three consecutive nights and checked daily. Mammal species were identified according to external morphology, fur color, measurements, and visible characters of dentition. Each animal's sex, developmental stage, and location were recorded at the time of sample processing. After identification of species, spleen tissues were removed from the animals and stored in liquid nitrogen until tested. For unidentified species in the field, craniums were brought to the laboratory for further identification.

\section{DNA Extraction and PCR Analysis}

DNA was extracted from spleen tissue using the DNA blood and tissue kits (Tiangen Biotechnique, Beijing, China) according to the manufacturer's instruction. A nested PCR for the 5S-23S rRNA intergenic spacer gene of BBSL, with the first-round primers (5'-CGACCTTCTTCGCC TTAAAGC-3' and 5'TAAGCTGACTAATACTAATTACCC-3') and second round primers (5'-TCCTAGGCATTCACCATA-3' and 5'CTGCGAGTTCGCG GGAGA-3' was performed as previously described [6]. The 252bp PCR-positive amplicons were directly sequenced using an automated DNA sequencer (ABI PRISM 373; Perkin-Elmer, Norwalk, CT). Sequence analysis was carried out using a FASTA search of the GenBank database, with phylogenetic trees constructed using MEGA software, version 6.06 [7]. The 5S-23S rRNA intergenic spacer gene sequences of BBSL obtained in this study were deposited in GenBank under accession numbers MK333406-MK33427 and KP677523.1 respectively.

\section{Statistical Analysis}

Univariate analysis was used to access the association between gender, developmental stage of small mammals, environmental landscape, altitude, and positive detection rate of BBSL. using a chi-square test. All variables with a $P$-value of $<0.05$ from univariate analysis were included in a multivariate forward stepwise logistic regression. All analyses were conducted using SPSS (version 17.0, SPSS Inc. Chicago, IL).

\section{Results}

A total of 3659 small mammals belonging to 57 species were collected (Table 1). The Apodemus draco was the most common species captured $(15.82 \%$, 579/3659), followed by Rattus tanezumi $(15.66 \%$, $573 / 3659)$. A total of 146 (3.99\%) small mammals tested positive for BBSL, with Ochotona gloveri (33.33\%, 1/3), Sorex cylindricauda (14.28\%, 7/49), Episoriculus leucopus $(14.94 \%, 13 / 87)$, and Rattus tuekkestanicus $(14.28 \%, 1 / 7)$ actively infected with BBSL. There was no significant difference in prevalence and BBSL genospecies, according to the small mammal species, sex or age, 
respectively. Positive samples were found in 14 of 23 sample counties (Figure 1), including Deqin, Weixi, Yulong, Gongshan, Fugong, Jinggu, Tengchong, Yongde, Menghai, Yunxian, Shiping, Mile, Yiliang and Yunlong, with Gongshan (S1) having the highest prevalence (8.58\%), followed by Deqin (S2, 7.85\%), and Yiliang (S16, 6.38\%).

The prevalence of BBSL in small mammals in forested landscapes, agricultural landscapes and residential landscapes were $5.19 \%, 3.14 \%$ and $0.63 \%$, respectively $\left(\chi^{2}=14.945, p=0.001\right)$ (Table 2). A significant difference in BBSL was observed by altitude class ( $<1500$ meters, 1500-2500 meters, $>2500$ meters), with $0.80 \%, 2.92 \%$ and $5.86 \%$, detected prevalence respectively $\left(\chi^{2}=43.089, p=0.001\right)$. The multivariate logistic regression analysis also suggest that samples found at altitudes greater than 1500 meters and in agricultural landscapes were more likely to be infected with BBSL (OR 4.524, 95\% CI 1.98 10.34; $p<0.01)$.

\section{Discussion}

We documented BBSL infection in 30 species of small mammal, among which, 20 species had not been previously documented. These species may be incidental hosts that are infected occasionally, further study is required to determine what, if any, role the play as reservoir hosts. The Rattus tanezumi (15.66\%) was the predominant species trapped in residential areas in Yunnan. Apodemus spp. (31.35\%) were the predominant hosts captured in Yunnan, which was consistent with results from Europe where Apodemus are considered a major reservoir of Borrelia [17]. BBSL was detected in A. draco and in A. chevrieri in Yunnan, with $A$. draco capable of carrying four pathogenic Borrelia spp. Soriculus leucops had a much higher prevalence ( $>14 \%$ ) with a larger sample sizes in this study than in other provinces in China [12; 1822]. Rattus norvegicus, the prominent household species in Yunnan, had a relatively high prevalence $(2 / 16,12.50 \%)$, although only 16 small mammals were captured, and tested positive for pathogenic genotypes $B$. afzelii and $B$. burgdorferi sensu stricto. We also found that Sorex cylindricauda tested positive for BBSL DNA (14.28\%), requiring further investigation to fully understand their role in maintaining or amplifying infections in nature.

Our findings indicated that detection rates in small mammals were ranked highest to lowest by landscape type as follows: forest landscape > agricultural landscape > residential landscape, which is likely related to tick vector density and preferred habitat. Sampling locations in this survey contained a broad range of altitudes from 500 meters to 4500 meters. Among the three altitude classes, the highest prevalence of BBSL was found above $2500 \mathrm{~m}$. In the Czech Republic, the distribution of Ixodes ricinus, a known vector of LB, extended toward higher altitudes, probably in relation to warming climates [23]. The roles temperature and humidity play in tick reproduction and reservoir preferences requires further investigation within these altitude ranges. Additionally, there are no reported human cases at these heights, which might reflect lower populations living in these areas.

Our study found five genospecies of BBSL in small mammals in Yunnan Province, four of them, excluding B. japonica, have previously been associated with LB [24-25]. Borrelia afzelii was the prominent 
genotype (56.84\%) in this study, which was detected in 24 species. There exists a wide distribution and genetic diversity of BBSL in Yunnan, compared to only 1-2 genospecies of BBSL in most provinces in China, such as Qinghai, Zhejiang, Guizhou and Guangxi. According to the sequences detected in this study, most $B$. afzelii shared $99 \%$ identity with clinical isolates from patients in northeastern China [26]. The $B$. burgdorferi sensu stricto sequences were identical to the sequence from a human case reported in France. At this time, there have been no confirmed patients with PCR confirmed LB in Yunnan province, requiring further investigation in the near future. The sequence of $B$. valaisiana obtained from small mammals cluster into two clades, one cluster fell within the sequence identities from Guizhou and Zhejiang province, the other cluster fell within close proximity to sequences from Europe. Birds are major reservoirs for $B$. valaisiana in Europe, however the transmission cycle maintaining $B$. valaisiana in Yunan may be different from other areas. Borrelia japonica was only detected in Yunlong county, with this representing the first report documentation of B. japonica in Apodemus draco and Niviventer excelsior in China. Borrelia garinii is the most common genospecies in China [27], but was only detected in Deqin County in this study. We found that $B$. afzelii was the main genospecies detected in Yunnan, which is consistent with previous reports [4]. Borrelia burgdorferi sensu stricto has been detected in Sika deer from Jilin province and in Caprolagus sinensis from Hunan province, and detected in small mammals in Yunnan province within the more populated counties of Gongshan, Deqin, and Weixi (S1, S2, S5) found in northwestern Yunnan (Figure 1). These findings reflect a high level of Borrelia genetic diversity found in a wide range of small mammals, many of which are likely reservoirs for BBSL in Yunnan.

In conclusion, Yunnan Province is an important natural focus of BBSL in China. Given the absence of reported human cases within this region, efforts to expand clinical surveillance are urgently needed.

\section{Abbreviations}

BBSL: Borrelia burgdorferi sensu lato; LB: Lyme borreliosis; IFA: Indirect Immunoinfluscent Assay; PCR: polymerase chain reaction; OR: Odds ratio; $95 \% \mathrm{Cl}$ : $95 \%$ confidence interval

\section{Declarations}

\section{Acknowledgements}

The authors wish to thank all the people who had collected small mammal samples in the field.

\section{Availability of data and materials}

The dataset used and analyzed by the authors during the present study are available from the corresponding author upon reasonable request.

\section{Authors' contributions}


$\mathrm{CD}$ and $\mathrm{JJ}$ conceived and designed the experiments. $\mathrm{ZH}, \mathrm{BJ}, \mathrm{YZ}, \mathrm{LT}$ and $\mathrm{MY}$ performed the experiments. $\mathrm{JJ}, \mathrm{ZH}$ and BJ analyzed the data. NJ and MV provided very constructive suggestions for revisions. Sample collections were implemented by ZG, ZS, ZL, YL and EP. All authors read and approved the final manuscript.

The research protocol for trapping wild small animals and collecting samples was approved by the Animal Subjects Research Review Boards at the Yunnan Institute of Endemic Diseases Control and Prevention (2011-005), in accordance with the medical research regulations of China and the Regulation of the People's Republic of China for the Implementation of the Protection of Terrestrial Wildlife. The efforts were made to avoid trapping in protected habitats.

\section{Consent for publication}

All authors approved the final submitted version of the manuscript and consented for publication.

\section{Competing interests}

The authors declare that they have no competing interests.

\section{References}

1. Schwartz A, Hinckley A, Meadet P, Hook S, Kugeler K. Surveillance for Lyme Disease - United States, 2008-2015. MMWR Surveill Summ. 2017, 66, 1-12.

2. Leeflang MM, Ang CW, Berkhoutet J, Bijlmer, HA, Bortel WV, Brandenburg AH, et, al. The diagnostic accuracy of serological tests for Lyme borreliosis in Europe: a systematic review and meta-analysis. BMC Infect Dis. 2016. 16:140.

3. Toshiyuki M. Terrestrial distribution of the Lyme borreliosis agent Borrelia burgdorferi sensu lato in East Asia. Jpn J Infect Dis. 2004. 57: 229-235.

4. Hao Q, Hou XX, Geng Z, Wan KL. Distribution of Borrelia burgdorferi Sensu Lato in China. J Clin Microbiol. 2011. 49: 647-650.

5. Hao Q. Epidemic situation and control measures of Lyme disease. Chin J Vector Biol \& Control. 2020. 31: 633-635.

6. Postic D, Assous MV, Grimont PA, Baranton G. Diversity of Borrelia burgdorferi sensu lato evidenced by restriction fragment length polymorphism of rrf (5S)rrl (23S) intergenic spacer amplicons. Int J Syst Bacteriol. 1994. 44: 743-752.

7. Tamura K, Peterson D, Peterson N, Stecher G, Nei M, Kumar S. MEGA5: molecular evolutionary genetics analysis using maximum likelihood, evolutionary distance, and maximum parsimony methods. Mol Biol Evol. 2011. 28: 2731-2739.

8. Wu XB, Na RH, Wei SS, Zhu JS, Peng HJ. Distribution of tick-borne diseases in China. Parasit Vectors. 2013. 6: 119. 
9. Wan KL, Zhang ZF, Li YL, Hao JG, Xia XZ, Hu XW, et, al. Lyme disease spirochete isolated from the kidney of Rattus coxingi in Sichuan province. Chin J Vector Biol Control. 1991. 6: 384-385.

10. Pan L, Yu ES. Study of Lyme Disease in Fujian Province. Chin J Public Health. 1992. 5: 271-272.

11. Shi SZ, Liu ZJ, Sun Y, Gong ZW, Zhang JJ. Investigation on small animals infection of Borrelia burgdorferi in Diebu forest. Chin J Hyg Insect Eq. 2004. 4: 220-221.

12. Huang HN, Ding Z, He J, Wu XM, Jiang BG, Gao Y, et, al. Investigation on Borrelia burgdorferi infection in ticks and animals from a forest area of Jinlin province. Chin J Zoonoses. 2006. 22: 785788.

13. Zhang DC, Hong Y, Zhong ZQ, Sun GJ, Dong SD, Zhang ZF, et, al. Lyme disease spirochete isolated from Rodents and Ticks in Liaoning province. Chin J Vector Biol Control. 1992. 6: 384-385.

14. Hou XX, Geng Z, Hao Q, Zhang Y, Wan KL. Rats, the primary reservoir hosts of Borrelia burgdorferi, in six representative provinces, China. Chin J Zoonoses. 2010. 26:1034-1036.

15. Meng Z, Jiang LP, Li ZL, Ying KM, Ling F, Lu QY. Infection with Lyme Spirochetes Detected in Rodents of Zhejiang Middle Area. Chin J Health Lab Technol. 2010. 20: 2503-2505.

16. Chen WS, Luo HM, He JF, Zheng K, Li W, Chen RA. Survey on Host and Vector of Lyme Disease in Guangdong Province. Chin J Vector Biol Control. 2000. 11: 190-193.

17. Sala V, Faveri ED. Epidemiology of Lyme Disease in Domestic and Wild Animals. Open Dermatol J. 2016. 10: 15-26.

18. Zhang F, Wang W, Li L. Borrelia Burgdorferii Infection and Genotypes in Ticks and Rodents Collected in Qinghai Province. J Prev Med Chin PLA. 2016. 34: 799-802.

19. Wang DM, Hao Q, Cai XH, Wan KL, Wang, ZX, Chen J. Study on ribotyping of Lyme borreliosis spirochete in Guizhou province. Chin J Epidemiol. 2003. 24: 1129-1131.

20. Zhang JJ, Zhang F, Li L, Liu ZJ. Borrelia burgdorferi infection and their genotypes in ticks and rodents collected from Maijishan region, Gansu Province, China. Chin J Zoonoses. 2015. 31: 357360 .

21. Chu CY, He J, Zhao QM, Zhang PH, Wu XM, Jiang BG, et, al. Molecular epidemiological studies on Borrelia burgdorferi in rodents collected in the forest area of several provinces and autonomous regions of China. Chin J Zoonoses. 2006. 22: 817-820.

22. Wulantuya, Gaowa, Yin XH, Cao MZ, Guo SC, Wang Q, Arionjergal, et, al. Survey on Borrelia bacteria in rodents from Baynanur, Inner Mongolia Autonomous Region. Chin J Vector Control. 2018. 29: 239241.

23. Daniel M, Danielová V, Kř́ž B, Jirsa A, Nozicka J. Shift of the Tick Ixodes ricinus and Tick-Borne Encephalitis to Higher Altitudes in Central Europe. Eur J Clin Microbiol Infect Dis. 2003. 22: 327-328.

24. Rudenko N, Golovchenko M, Grubhoffer L, Oliver JH Jr. Updates on Borrelia burgdorferi sensu lato complex with respect to public health. Ticks Tick Borne Dis. 2011. 2: 123-128.

25. Diza E, Papa A, Vezyriet E, Tsounis S, Milonas I, Antoniadis A. Borrelia valaisiana in cerebrospinal fluid. Emerg Infect Dis. 2004. 10: 1692-1693. 
26. Ni XB, Jia N, Jiang BG, Sun T, Zheng YC, Huo QB, et, al. Lyme borreliosis caused by diverse genospecies of Borrelia burgdorferi sensu lato in northeastern China. Clin Microbiol Infect. 2014. 20: 808-814.

27. Fang LQ, Liu K, Li XL, Liang S, Yang Y, Yao HW, et, al. Emerging tick-borne infections in mainland China: an increasing public health threat. Lancet Infect Dis. 2015. 15: 1467-1479.

\section{Tables}

Table 1. Prevalence of Borrelia burgdorferi sensu lato in different species of small mammals. 


\begin{tabular}{|c|c|c|c|c|c|c|}
\hline Mammal Species & $\begin{array}{l}\text { Positive/Tested } \\
\text { (\%) }\end{array}$ & $\begin{array}{l}\text { B. } \\
\text { afzelii }\end{array}$ & $\begin{array}{l}\text { B. } \\
\text { burgdorferi }\end{array}$ & $\begin{array}{l}\text { B. } \\
\text { garrinii }\end{array}$ & $\begin{array}{l}\text { B. } \\
\text { valaisiana }\end{array}$ & $\begin{array}{l}\text { B. } \\
\text { japonica }\end{array}$ \\
\hline Rattus tanezumi & $4 / 573(0.7)$ & 3 & 0 & 0 & 1 & 0 \\
\hline $\begin{array}{l}\text { Rattus } \\
\text { tuekkestanicus }\end{array}$ & $1 / 7(14.3)$ & 1 & 0 & 0 & 0 & 0 \\
\hline Rattus norvegicus & $2 / 16(12.5)$ & 1 & 1 & 0 & 0 & 0 \\
\hline $\begin{array}{l}\text { Rattus } \\
\text { brunneusculus }\end{array}$ & $2 / 94(2.1)$ & 1 & 0 & 0 & 1 & 0 \\
\hline $\begin{array}{l}\text { Apodemus } \\
\text { latronum }\end{array}$ & $9 / 166(5.4)$ & 1 & 1 & 7 & 0 & 0 \\
\hline Apodemus chevrieri & $20 / 402(5.0)$ & 16 & 1 & 3 & 0 & 0 \\
\hline Apodemus draco & 19/579 (3.3) & 10 & 5 & 3 & 0 & 1 \\
\hline Mus caroli & $3 / 75(4.0)$ & 3 & 0 & 0 & 0 & 0 \\
\hline Mus pahari & 6/91 (66) & 6 & 0 & 0 & 0 & 0 \\
\hline $\begin{array}{l}\text { Niviventer } \\
\text { andersoni }\end{array}$ & $3 / 57(5.3)$ & 0 & 0 & 2 & 1 & 0 \\
\hline Niviventer eha & $2 / 32(6.3)$ & 0 & 2 & 0 & 0 & 0 \\
\hline $\begin{array}{l}\text { Niviventer } \\
\text { confucianus }\end{array}$ & $14 / 144(9.7)$ & 6 & 1 & 7 & 0 & 0 \\
\hline Niviventer excelsior & $1 / 29(3.5)$ & 0 & 0 & 0 & 0 & 1 \\
\hline Eothenomys eleusis & $12 / 160(7.5)$ & 8 & 4 & 0 & 0 & 0 \\
\hline $\begin{array}{l}\text { Eothenomys } \\
\text { cachinus }\end{array}$ & 4/38 (10.5) & 3 & 1 & 0 & 0 & 0 \\
\hline Eothenomys custos & $2 / 95(2.1)$ & 1 & 1 & 0 & 0 & 0 \\
\hline Pitymys leucurus & $1 / 42(2.4)$ & 0 & 0 & 1 & 0 & 0 \\
\hline Volemys clarkei & $2 / 35(5.7)$ & 1 & 0 & 1 & 0 & 0 \\
\hline Dremomys pernyi & $3 / 26(11.5)$ & 0 & 0 & 3 & 0 & 0 \\
\hline Crocidura attenuata & $2 / 41(4.9)$ & 1 & 0 & 0 & 1 & 0 \\
\hline Crocidura dracula & $1 / 62(1.6)$ & 1 & 0 & 0 & 0 & 0 \\
\hline Soriculus caudatus & $1 / 46(2.2)$ & 1 & 0 & 0 & 0 & 0 \\
\hline $\begin{array}{l}\text { Episoriculus } \\
\text { leucops }\end{array}$ & $13 / 87(14.9)$ & 6 & 7 & 0 & 0 & 0 \\
\hline Sorex alpinus & $1 / 25(4.0)$ & 1 & 0 & 0 & 0 & 0 \\
\hline
\end{tabular}




\begin{tabular}{|lllllll|}
\hline $\begin{array}{l}\text { Sorex cylindricauda } \\
\text { squamipes }\end{array}$ & $7 / 49(14.3)$ & 6 & 1 & 0 & 0 & 0 \\
\hline Suneus murinus & $2 / 114(1.8)$ & 0 & 2 & 0 & 0 & 0 \\
\hline Nasillus gracilis & $1 / 59(1.7)$ & 1 & 0 & 0 & 0 & 0 \\
\hline Ochotona thibetana & $6 / 31(3.2)$ & 1 & 0 & 0 & 0 & 0 \\
\hline Ochotona gloveri & $1 / 3(33.3)$ & 3 & 0 & 3 & 0 & 0 \\
\hline Others & $0 / 389(0)$ & 0 & 0 & 0 & 0 & 0 \\
\hline Total & $146 / 3659(4.0)$ & 83 & 27 & 30 & 4 & 2 \\
\hline
\end{tabular}

Table 2. Risk factors related to Borrelia burgdorferi sensu lato based on univariate analyses.

\begin{tabular}{|lllll|}
\hline variable & simple size & BBSL Infection & & \\
\cline { 2 - 5 } & constituent ratio (\%) & positive rate (\%) & $\chi^{2}$ & $P$ \\
\hline altitude $(\mathrm{m})$ & & & & \\
\hline 1500 & $868 / 3659(23.72 \%)$ & $7 / 868(0.81 \%)$ & & \\
\hline $1500 \sim 2500$ & $823 / 3659(22.49 \%)$ & $24 / 823(2.92 \%)$ & 43.089 & 0.001 \\
\hline $2500 \sim$ & $1968 / 3659(53.79 \%)$ & $115 / 1968(5.84 \%)$ & & \\
\hline gender & & & & \\
\hline male & $1753 / 3659(47.91 \%)$ & $81 / 1753(4.62 \%)$ & 3.492 & 0.062 \\
\hline female & $1906 / 3659(52.09 \%)$ & $65 / 1906(3.41 \%)$ & & \\
\hline age & & & & \\
\hline adult & $3337 / 3659(91.20 \%)$ & $133 / 3337(3.99 \%)$ & 0.002 & 0.964 \\
\hline pubertal & $322 / 3659(8.80 \%)$ & $13 / 322(4.04 \%)$ & & \\
\hline landscape & & & & \\
\hline residential & $158 / 3659(4.32 \%)$ & $1 / 158(0.63 \%)$ & & \\
\hline agricultural & $1786 / 3659(48.81 \%)$ & $56 / 1786(3.14 \%)$ & 14.945 & 0.001 \\
\hline forest & $1715 / 3659(46.87 \%)$ & $89 / 1715(5.19 \%)$ & & \\
\hline Total & & $146 / 3659(3.99 \%)$ & & \\
\hline
\end{tabular}

\section{Figures}




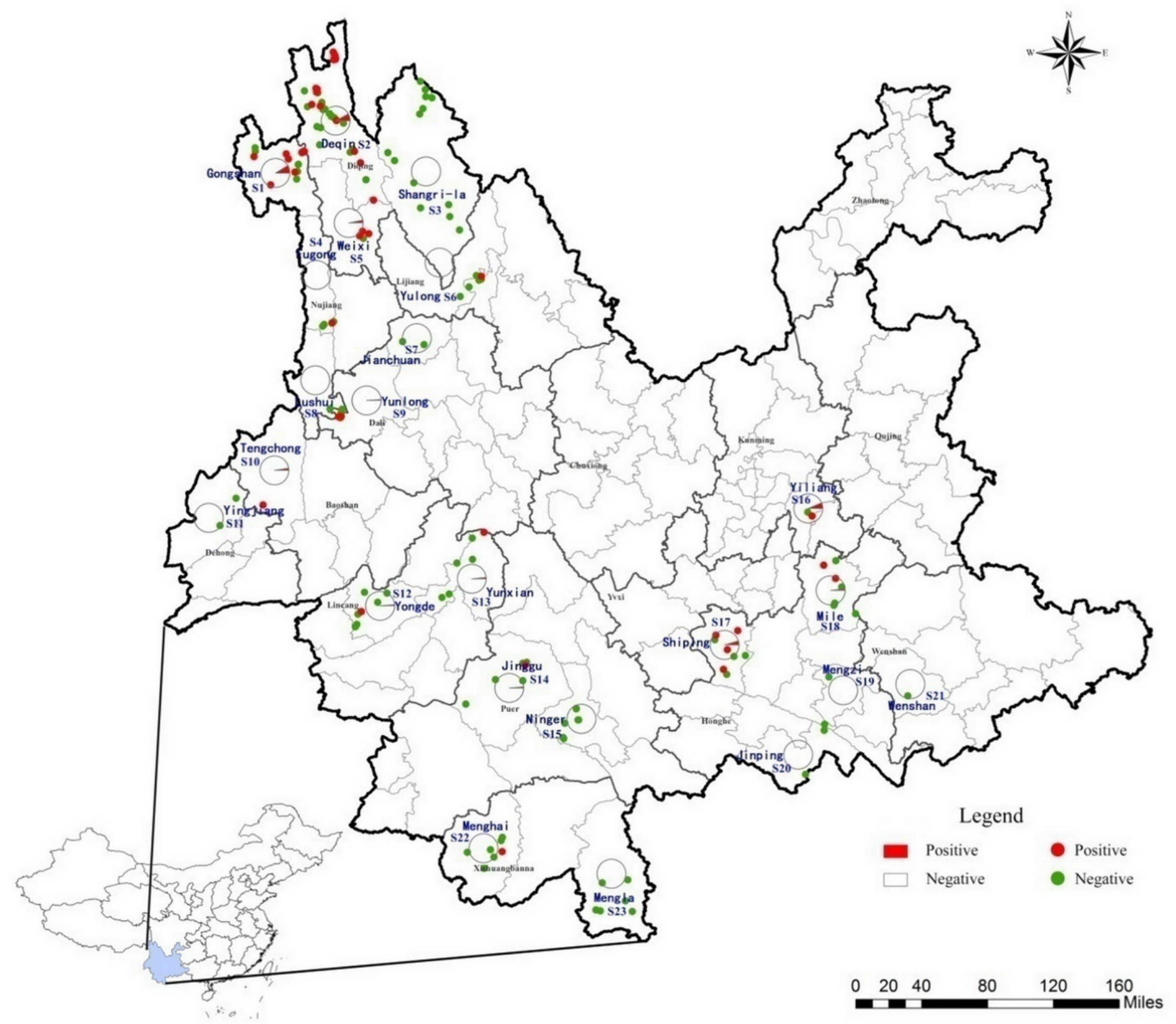

Figure 1

The distribution of sampling sites and prevalence of Borrelia burgdorferi sensu lato in Yunnan Province. A total of 3659 small mammals were collected from 23 sample counties, including 14 positive sample counties (Deqin, Weixi, Yulong, Gongshan, Fugong, Jinggu, Tengchong, Yongde, Menghai, Yunxian, Shiping, Mile, Yiliang and Yunlong). Note: The designations employed and the presentation of the material on this map do not imply the expression of any opinion whatsoever on the part of Research Square concerning the legal status of any country, territory, city or area or of its authorities, or concerning the delimitation of its frontiers or boundaries. This map has been provided by the authors. 


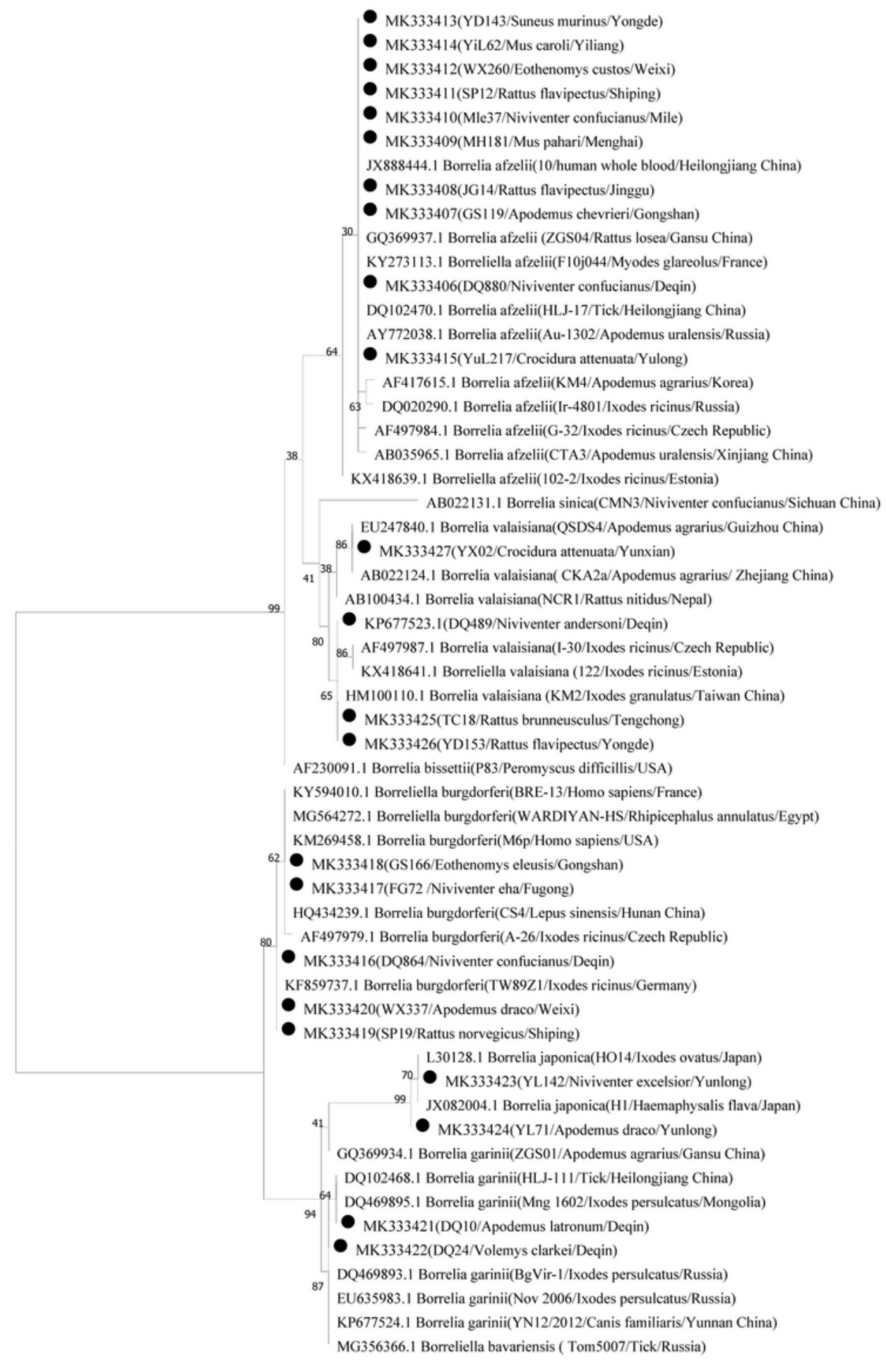

Figure 2

Phylogenetic tree of 252bp of 5S-23S rRNA intergenic spacer gene of Borrelia burgdorferi sensu lato. Maximun Likelihood phylogenetic tree based on a comparison of Borrelia burgdorferi sensu lato 5S-23S rRNA intergenic spacer gene sequences obtained from Yunnan small mammals with Borrelia burgdorferi sensu lato reference strains. The number on each branch shows the percent occurrence in 1000 bootstrap replicates. Black circles stood for novel sequences identified in this study. 


\section{Supplementary Files}

This is a list of supplementary files associated with this preprint. Click to download.

- GraphicalAbstract.pptx 